\title{
Effect of elevated temperature on geo-polymer concrete - A Review
}

\author{
Chandrakanth $\mathrm{V}^{1^{*}}$, and Srikanth Koniki ${ }^{*}$ \\ ${ }^{1}$ PG student, Civil Engineering Department, GRIET, Hyderabad, India \\ ${ }^{2}$ Associate Professor, Civil Engineering Department, GRIET, Hyderabad, India
}

\begin{abstract}
The study on the effect of elevated temperature on Geo-polymer concrete (GPC) got its significance because conventional concrete start to deteriorate around $400^{\circ} \mathrm{C}$. GPC gains attention as it is eco-friendly and economical, by utilizing industrial by-products. GPC also an alternate solution as the raw materials to produce cement are depleting day by day. GPC gains strength by geo-polymerization with the reactions between mineral admixtures and alkaline solutions. This paper presents the studies on general properties and advantages of GPC over conventional concrete which depend on properties of binder, type of curing etc. Current study mainly concentrates on effect of elevated temperatures and post fire properties of GPC depending upon rate of heating, duration of fire and maximum high temperature. Strength and durability recovery of fire damaged concrete is discussed.
\end{abstract}

\section{Introduction}

Concrete is second most used material in the world only after water. The rate of demand for concrete increasing exponentially day by day. Cement being major component used in concrete, producing cement is inevitable. Almost one tonne of $\mathrm{CO}_{2}$ is released into the atmosphere for producing one tonne of cement i.e. 0.55 tonne due to the calcination process of lime and 0.40 tonne due to consumption of fuel which shows negative impact on environment [1]. Apart fire accidents show major impact on concrete structures, even though concrete is one of the better fire resisting material. Concrete starts to deteriorate and loss its strength from $400^{\circ} \mathrm{C}$ and completely deteriorate at $800^{\circ} \mathrm{C}$ [2]. And also conventional concrete is effective for the post fire recovery methods only if exposed temperature is below $600^{\circ} \mathrm{C}[3]$.

Blended cements in which mineral admixtures (by products of industries) are added to clinker which lower the use of raw materials and minimise the $\mathrm{CO}_{2}$ emissions to some extent. But replacement of admixtures is limited to an optimum content further which shows negative results [4]. As also raw materials for the production of cement is depleting rapidly, in this regard development of no cement concrete gained attention for researchers.

With further research on inorganic cementitious components which are rich in aluminates and silicates proposed them to use as binders. These binders can be activated by alkaline solution gives them cementitious properties by the process of poly-condensation reaction [5]. These reaction is one of the processes of Geopolymerisation giving them the name Geo-polymers proposed by J Davidovits [6]. Utilising these materials not only reduces $\mathrm{CO}_{2}$ emission (due to production of cement) but can also be produce better fire resisting concrete compared to conventional concrete [7]. The chemical composition of different mineral admixtures which can be used as binders through geo-polymerisation is given in table 1 .

Table 1. Chemical Composition of Mineral admixtures.

\begin{tabular}{|c|c|c|c|c|c|c|c|c|c|c|}
\hline \multirow{2}{*}{ Constituents } & \multicolumn{10}{|c|}{ Composition (Mass \%) } \\
\hline & $\mathrm{SiO}_{2}$ & $\mathrm{Al}_{2} \mathrm{O}_{3}$ & $\mathrm{Fe}_{2} \mathrm{O}_{3}$ & $\mathrm{CaO}$ & $\mathrm{MgO}$ & $\mathrm{Na}_{2} \mathrm{O}$ & $\mathrm{K}_{2} \mathrm{O}$ & $\mathrm{SO}_{3}$ & $\mathrm{TiO}_{2}$ & $L O I$ \\
\hline Fly Ash [15] & $53-57$ & $25-35$ & $3-7$ & $4-6$ & $1.0-2.5$ & $\begin{array}{c}0.10- \\
0.25\end{array}$ & $0.10-1.43$ & -- & 1.08 & $1-3$ \\
\hline RHA [16] & $91-97$ & $\begin{array}{c}0.20- \\
0.35\end{array}$ & $\begin{array}{c}0.30- \\
0.50\end{array}$ & $0-1$ & $\begin{array}{c}0.30- \\
0.81\end{array}$ & 0.08 & $1.30-3.21$ & 1.21 & $0.0-0.8$ & -- \\
\hline OPC [17] & $20-22$ & $4-5$ & $2-5$ & $60-65$ & $0.5-2.0$ & $0.2-0.5$ & $0-0.76$ & $2-2.27$ & -- & 3.10 \\
\hline
\end{tabular}

\footnotetext{
${ }^{1}$ Chandrakanth V: vck1729@gmail.com
}

2 Srikanth Koniki: sri.sri001@gmail.com 


\begin{tabular}{|c|c|c|c|c|c|c|c|c|c|c|}
\hline GGBS [18] & 33.28 & 17.47 & 0.65 & 35.59 & 8.10 & 0.35 & 0.48 & -- & 0.75 & 1.74 \\
\hline MK [19] & $47-57$ & $30-37$ & $1.5-6.0$ & $\begin{array}{c}0.50- \\
1.77\end{array}$ & $\begin{array}{c}0.30- \\
0.76\end{array}$ & -- & $1.68-2.5$ & $0-1.73$ & $0-1.52$ & $0-5.40$ \\
& & & & & & & & & \\
\hline AF [20] & $30-35$ & $20-22$ & $1.2-2.5$ & $20-36$ & $4-8$ & $0-0.5$ & $0.0-0.75$ & $0.1-0.3$ & -- & $0.0-1.0$ \\
\hline
\end{tabular}

\subsection{Geo-polymerisation, Geo-cements and Geo-polymer concrete}

Geo-polymerisation is a process of chain reaction of combining monomers to polymers, while the alkaline solution acts as buffer which enhance the strength properties from the reaction of alumina silicates present in the geo-polymers [8].Though it is complicated to understand the geo-polymerisation concepts, a brief conceptual model of given in Fig. 1[9]. The Geopolymerisation process of mineral admixtures follow the model presented by Glokovsky to change the phase from amorphous to semi-crystallization[10]. The steps involved are Destructive Coagulation, Coagulation condensation and Condensation-Crystallisation forming silica-aluminate structures of Poly (sialate), Poly (sialatesiloxo), Poly (sialate-disiloxo), where sialate refer to Silica-aluminate [10].

From the hydration of OPC (ordinary Portland cement), C-S-H (calcium silicate hydrates) gel and $\mathrm{CH}$ (calcium hydrates) are formed. Excess amount of lime results in excess production of $\mathrm{CH}$ which will further react with sulphates surrounding it and lead to expansion and cracking of the element especially walls and slabs known to be sulphate attack $[11,12]$. But the lime content is essential for the strength of the concrete, hence by using geo-polymers we can try to eliminate sulphate attack as the aluminates present in the geo-polymers react with $\mathrm{CH}$ and forms C-A-S-H (calcium alumina silicate hydrates) gel which further improve the strength [13]. The lime content in geo-polymers is less than that of OPC, reducing the $\mathrm{CH}$ content by hydration which leads in increase the pores and its size forming cracking and spalling in concrete. Spalling especially occurs if the moisture content is more than 3 to $4 \%$ [14]. Hence GPC (geopolymer concrete) helps in reducing the levels of $\mathrm{CH}$, pores and cracks at ambient and high temperatures [13].

Properties of GPC depend on several parameters such as chemical and physical properties of binders like alkaline solution to binder ratio, $\mathrm{pH}$ of alkaline solution, percentage of compounds like $\mathrm{SiO}_{2}, \mathrm{Na}_{2} \mathrm{O}, \mathrm{CaO}, \mathrm{Al}_{2} \mathrm{O}_{3}$ etc., molarity of $\mathrm{NaOH}$ each has their own significance[8,21-23]. Mixing time, type and age of curing also alter the properties of GPC. The unique properties of GPC which include high early strength, low shrinkage, freeze-thaw resistance, sulphate resistance and corrosion resistance, make them ideal to replace OPC concrete [22]. The high alkali admixtures do not generate any Alkali-Aggregate reaction [23]. These advantages makes it in the application of Pre-cast railway sleepers, lightweight materials and Fire protection coatings [24].

\section{Significance of the study}

The scope to utilise GPC for structural members is analysed. Post fire properties of GPC, property recovery methods are discussed. Implementation of repairs on field is reviewed. Mechanical and durable properties of GPC using different geo-polymers is studied as there is a future scope to use new geo-polymer materials in abundant. The need to use the GPC as an eco-friendly, noble material is demonstrated.

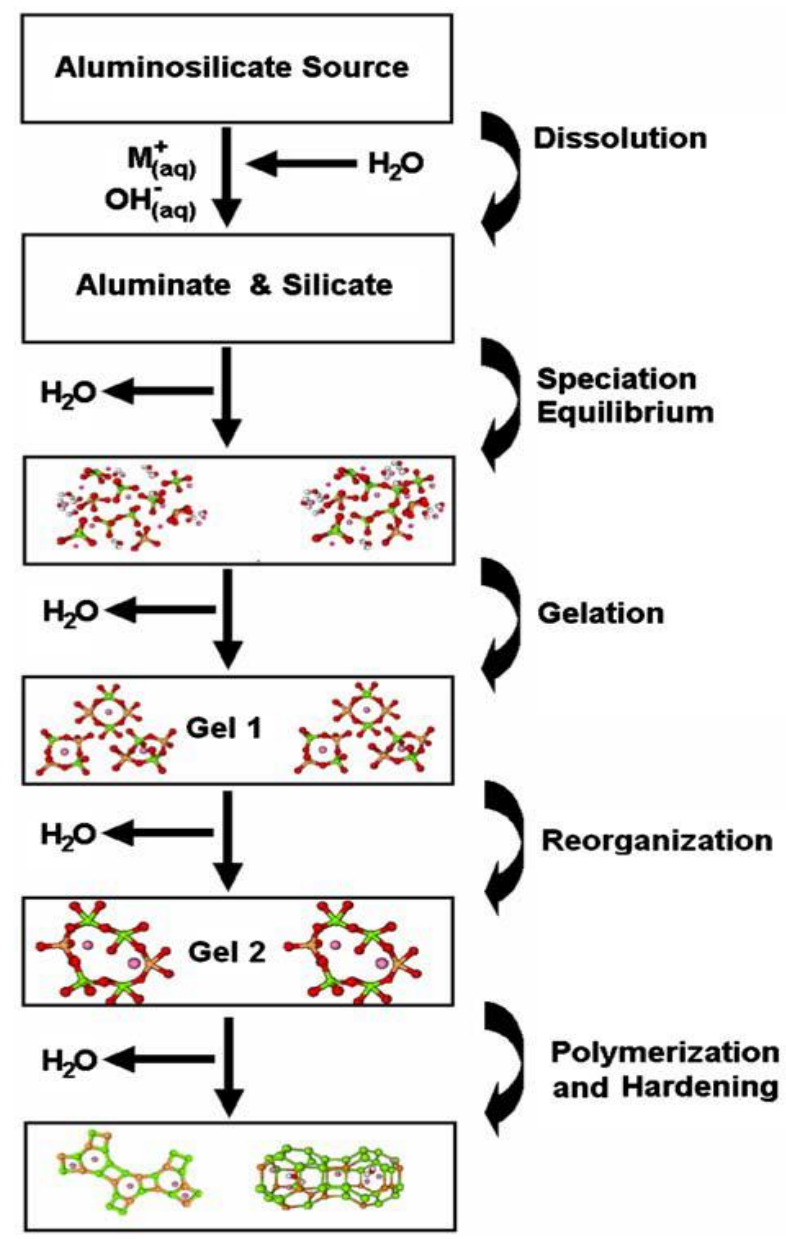

Fig. 1. Process of Geo-polymerisation [9]

\section{Study on effect of elevated temperature}

\subsection{Study on effect of elevated temperature on conventional concrete}

When concrete is exposed to fire, the micro structure is damaged in several phases based on parameters such as 
exposed temperature, time of exposure, moisture content in concrete at ambient temperature [4]. The mechanical decay at structural level is also observed due to spalling of concrete and reinforcing bar exposure to fire [2]. The phases of transformation of concrete are breakdown of cement gel structure, tendency to increase drying shrinkage, cracking and reduction in durability [25]. The phenomena occur due to fire on concrete are such as increase in porosity, dehydration of cement paste, loss of strength, thermal cracking, change in pore pressure and porosity which lead to thermal creep, decrease in moisture content [4]. The mechanical properties such as uniaxial compressive strength, split tensile strength reduces gradually up to a temperature rise of $400^{\circ} \mathrm{C}$ and after it, a rapid decrease can be seen and almost all the strength is lost at temperature about $800^{\circ} \mathrm{C}[2,13]$. Modulus of elasticity of concrete reduces rapidly with increase in temperature. Slope of stress-strain curve decreases which indicates that the ductility of concrete increases with temperature given in Fig. 2 [2].

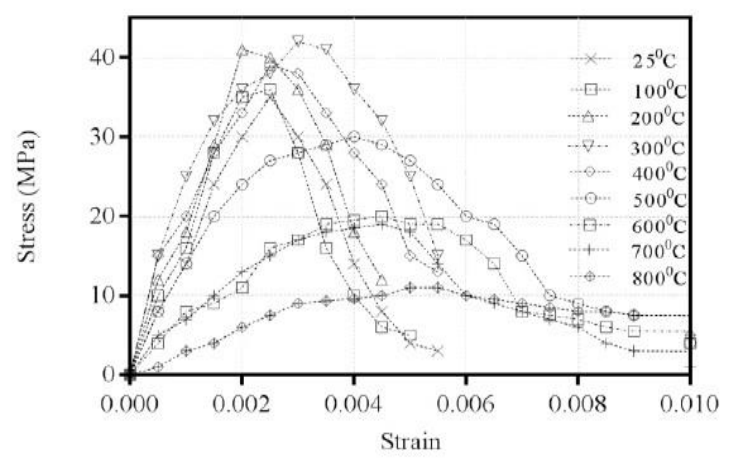

Fig. 2. Stress-strain behaviour of concrete under elevated temperature [2]

The decrease in the residual strength is due to formation and coarsening of pores with elevated temperature under unstressed condition. The moisture content in the concrete softens the cement gel and weakens surface forces between the cement gel particles. Under stressed condition, as the coarsening of pores is controlled due to applied load, there will be a lower reduction in the load carrying capacity of concrete exposed to fire, however above $400^{\circ} \mathrm{C}$, stressed and unstressed conditions show similar results [26]. The gel pore size increases with increase in shrinkage and decomposition of CSH gel with ET. When comparing with blended mixes, the OPC concrete show much voids at ET [27]. At ET, spalling size in concrete depends on the size of fracture process zone which depends on size of aggregate in all types of concretes with different binders. It shows that spalling is caused by physical factors [28]. Spalling probability depends on evaporable water content arising pore pressure which is major cause for spalling. The microstructural analysis at $600^{\circ} \mathrm{C}$ shows a spark like phase may be due to formation of spurrite is observed which is to be avoided. The $\mathrm{Ca} / \mathrm{Si}$ for conventional concrete increases with $\mathrm{ET}$, lead to formation of more $\mathrm{CH}$ which effects concrete [27]. After concrete exposed to fire, quick cooling has more loss in compressive strength than slow cooling may be due to thermal shock. The mass loss is constant up to $400^{\circ} \mathrm{C}$, may be due to loss of capillary water, adsorbed water and interlayer water there after the rate is lowered as the mass loss is due to chemically bound water $[29,30]$. From the SEM analysis, at the Interfacial Transition Zone (ITZ) it is observed that the pore area fraction is proportional to the ET [29].

\subsection{Study of elevated temperature on blended concrete}

The effect of ET on several other concretes like SCC, HSC, HPC, HVFAC using admixtures like FA, GGBS, MK, SF etc., are also observed by researchers. C Thomas investigated the effect of ET on heavy weight concrete using Magnetite as aggregate incorporating steel fibres, concluded that the strength of concrete is inversely proportional to temperature. The use of steel fibres slightly increase the split tensile strength subjected to fire [31]. The mechanical properties of SCC show a similarity with normal vibrated concrete (NVC) up to $200^{\circ} \mathrm{C}$ and further higher reduction in residual strength is observed compared with NVC. Explosive spalling is observed at $800^{\circ} \mathrm{C}$ is observed, may be due to pore water pressure above tensile strength due to intrusion of Silica fume in pores formed, the usage of super plasticizer does not have any effect [32]. The use of GGBS in concrete helps in reducing the loss of strength at higher temperatures forming CASH compounds as the slag particles fill in the pores formed and making the concrete stable [27].

HVFAC shows a better performance at ET at an optimum of $40 \%$ replacement of FA, and the stressed condition provokes the slag material to fill in pores and bind together firmly showing better results than unstressed condition [28]. Moisture content in concrete also effects the properties at ET, hence HSC and HPC having low water-cement ratios show better fire resistance than NSC [33].

\subsection{Study of elevated temperatures on Reinforced concrete members}

The effect of ET is also very crucial in case of RCC regarding the residual bond strength between concrete and reinforcing bars. The factors that affect the bond strength are compressive strength of concrete, spalling and cracking, concrete cover provided and the yielding of steel bar due to fire [34]. To support the above statement, pull-out tests and splitting failure tests are done on concrete with varying cover to the reinforcement for a cuboidal specimen and stated that, split failure is predominant in specimen with lesser cover to reinforcement and only pull-out failure observed in specimen provided bar at centre [35]. 


\subsection{Study of elevated temperature on Geo- polymer concrete}

GPC made with low calcium fly-ash show a reduction in strength up to $200^{\circ} \mathrm{C}$ due to initial water loss and further a slight increase in strength is observed in between $200^{\circ} \mathrm{C}$ to $400^{\circ} \mathrm{C}$ which happened due to further geopolymerisation [36,37]. The visual appearance of GPC and OPCC after ET, details that hairline cracks formed on OPCC at $200^{\circ} \mathrm{C}$ and further increased in size and no cracks formed on GPC surface until and up to $400^{\circ} \mathrm{C}$ and further small cracks are seen up to $800^{\circ} \mathrm{C}$ [37].

The binder-alkali ratio plays an important role in gaining strength of GPC at ambient and ET [38]. Accelerated curing helps in early gain of strength. Fly-ash based geo-polymer gave better residual strength after subjected to fire [39]. GPC that received extended heat curing exhibited higher compressive strength at all elevated temperatures because of additional geopolymerisation at extended time [40]. Aggregate inclusion to geo-polymer paste reduces post fire strength due to expansion of aggregate and contraction of geopolymer paste [41].The type and size of aggregate used, size of specimen of GPC, the thermal incompatibility between Geo-polymer matrix and aggregate will influence the properties under elevated temperature. Use of Granite CA and crushed FA shows better results than Basalt CA and Natural FA for GPC [42]. The use of superplasticiser in GPC leads to additional decreases in strength post fire condition [41].

The $\mathrm{SiO}_{2} / \mathrm{Al}_{2} \mathrm{O}_{3}$ depends on properties like setting time, composition of gel pastes and micro-structure of alkali activated material [42]. The formation of improved alumina silicate network at high temperatures during Geopolymerisation helps in increasing compressive strength. Smaller size CA has slight increase in strength due to less cracking in ITZ at ET [43]. The residual uniaxial compressive strength is increased up to a temperature of $200^{\circ} \mathrm{C}$ and then it tends to decrease and almost 20 percent of strength is decreases at $600^{\circ} \mathrm{C}$ further the loss is more rapid [3]. The shape of members has also impact on residual compressive strength after fire exposure. Farhad aslani, developed and proposed relationships for the compressive strength, elasticity modulus, and flexural strength of unstressed GPC with different geo-polymer resin composition, geo-polymeric binder type, and aggregate type at elevated temperature [44].

\section{Study on Recovery of Fire damaged concrete}

Recovery of fire damaged concrete is important as for some time we cannot avoid utilising the structure, for some reasons. Researchers investigated on this issue and found a way to recover the properties of fire damaged concrete that is recurring, which also may help further hydration of un-hydrated cement particles improving the properties of concrete[45,46]. The recovery depend on the factors such as type of recurring, type of concrete, ET, age of concrete, time of exposure. However faster rate, time of re-curing does not affect the amount of recovering properties. Although, by re-curing the porosity and cement matrix properties are recovered which can repair cracks is done well and can be suited to pre-fire levels, but residual mechanical properties cannot be recovered to unheated level this may be due to loss of density and compaction in microstructural level [45]. As per chi-sun poon continuous moisture content for 7 days can improve recovering properties and thereafter the recovery rate slows down. Concrete exposed to $600^{\circ} \mathrm{C}$ show better recovery due to the maximum decomposed $\mathrm{CSH}$ at $550^{\circ} \mathrm{C}$ try to rehydrate more. Air curing shows a lower rate of recovery [46].

HSC shows better recovery than NSC due to dense microstructure and helps to refill the cavities during rehydration. Concrete with $40 \%$ fly-ash replacement has maximum recovery due to reaction between the slag compounds and fresh $\mathrm{CH}$ compounds formed during rehydration [46]. The surface of GPC after re-curing is clear due to absence of leaching [47].

A step wise procedure is followed to inspect the fire damaged structures to avoid any accidents, as demonstrated by W Y Lee given in Fig. 3. By ensuring the structure is safe for testing, non-destructive tests, partial destructive tests are implemented. Need to identify and extend the repairs needed and proceed for a selection of proper plan, process and materials required [48].

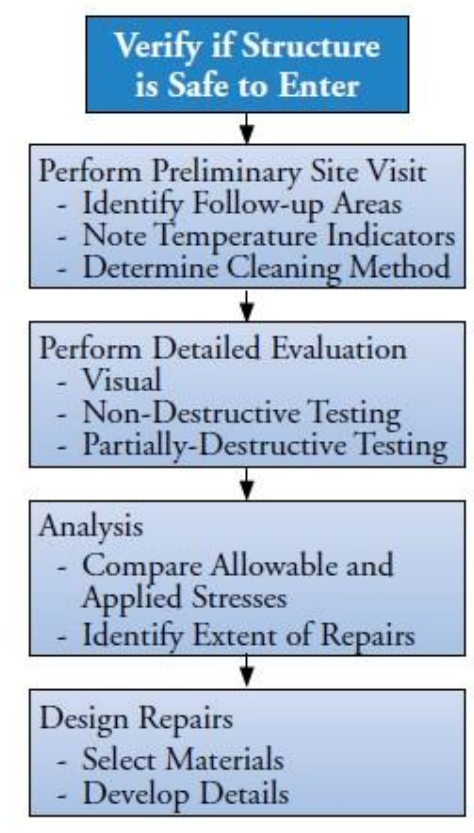

Fig. 3. Step wise procedure to inspect and repair fire damaged concrete structures [48].

\section{Future scope of the study}

To make aware the use of GPC in field for different types of structures which is not only eco-friendly but also economical. There is a scope to study the static and dynamic behaviour of structural members made from GPC. The scope to study the effect of elevated temperature on structural members made with GPC from different geo-polymers and their combinations. The study of curing effect on GPC can be studied in detail. New 
techniques and methods to improve conditions of fire damaged concrete can be researched and examined.

\section{Conclusions}

From this review paper we may conclude that:

- GPC is an eco-friendly and economical in case used in abundant.

- Most of the geo-polymer's grain size much lower than cement particles, filling of pores is done avoiding cracking.

- HSC and HPC can be made using GPC with less cost than done with OPC.

- GPC is a better material in case of fires, due to lower Water-binder ratio, further geo-polymerisation and filling of pores.

- Water quenching does not give better results as there occurs a thermal shock.

\section{References}

1. Davidovits J., Global warming impact on the cement and aggregates industries, World resource review, 6(2), 263-278 (1994).

2. Krishna D. A, Priyadarsini R. S \& Narayanan S., Effect of Elevated Temperatures on the Mechanical Properties of Concrete, Procedia Structural Integrity, 14, 384-394 (2019).

3. Rao G. M, Rao T. G, Reddy M. S. N \& Seshu D. R., A Study on the Strength and Performance of Geopolymer Concrete Subjected to Elevated Temperatures, Recent Advances in Structural Engineering, Volume 1 (pp. 869-889), Springer, Singapore (2019).

4. Siddique R \& Kaur D., Properties of concrete containing ground granulated blast furnace slag (GGBFS) at elevated temperatures, Journal of Advanced Research, 3(1), 45-51(2012).

5. Davidovits J., Geopolymers and geopolymeric materials, Journal of Thermal Analysis and Calorimetry, 35(2), 429-441 (1989).

6. Davidovits J., Geopolymers: inorganic polymeric new materials, Journal of Thermal Analysis and calorimetry, 37(8), 1633-1656 (1991).

7. Shaikh F. U. A, \& Vimonsatit V., Compressive strength of fly-ash-based geopolymer concrete at elevated temperatures, Fire and materials, 39(2), 174-188 (2015).

8. Lăzărescu A. V, Szilagyi H, Baeră C, \& Ioani A., The effect of alkaline activator ratio on the compressive strength of fly ash-based geopolymer paste, In IOP Conference Series: Materials Science and Engineering (Vol. 209, No. 1, p. 012064). IOP Publishing (June,2017).

9. Duxson P, Provis J. L, Lukey G. C, \& Van Deventer J. S., The role of inorganic polymer technology in the development of 'green concrete', Cement and Concrete Research, 37(12), 1590-1597 (2007).
10. Davidovits J., Properties of geopolymer cements, In First international conference on alkaline cements and concretes (Vol. 1, pp. 131-149), Kiev State Technical University, Ukraine: Scientific Research Institute on Binders and Materials (October,1994).

11. Shetty M. S., Concrete technology. S. chand \& company LTD, (2005).

12. Neville A. M., Properties of concrete (Vol. 4). London: Longman (1995).

13. Komnitsas K, \& Zaharaki D., Geopolymerisation: A review and prospects for the minerals industry, Minerals engineering, 20(14), 1261-1277 (2007).

14. Kodur V., Properties of concrete at elevated temperatures, ISRN Civil engineering (2014).

15. A. Ehsani, M. Nili, K. Shaabani., Effect of nanosilica on the compressive strength development and water absorption properties of cement paste and concrete containing Fly Ash, KSCE J. Civ. Eng. 21 (5), 18541865 (2017).

16. H. Chao-Lung, B. Le Anh-Tuan, C. Chun-Tsun, Effect of rice husk ash on the strength and durability characteristics of concrete, Constr. Build. Mater. 25 (9), 3768-3772 (2011).

17. A. Mehta, R. Siddique, Properties of low-calcium fly ash based geopolymer concrete incorporating OPC as partial replacement of fly ash, Constr. Build. Mater. 150, 792-807 (2017).

18. T. Yang, X. Yao, Z. Zhang, H. Wang, Mechanical property and structure of alkali-activated fly ash and slag blends, J. Sustain. Cement-Based Mater. 1 (4), 167-178 (2012).

19. P. Nuaklong, V. Sata, P. Chindaprasirt, Properties of metakaolin-high calcium fly ash geopolymer concrete containing recycled aggregate from crushed concrete specimens, Constr. Build. Mater. 161, 365373 (2018).

20. B.B. Jindal, D. Singhal, S.K. Sharma, D.K. Ashish, Parveen, Improving compressive strength of low calcium fly ash geopolymer concrete with alccofine, Advances In Concrete, Construction 5 (1), 17-29 (2017).

21. Phoo-Ngernkham $T$, Phiangphimai $C$, Damrongwiriyanupap N, Hanjitsuwan S, Thumrongvut J \& Chindaprasirt P., A mix design procedure for alkali-activated high-calcium fly ash concrete cured at ambient temperature, Advances in Materials Science and Engineering, (2018).

22. Naspuri Arun Raju, T. Suresh Kumar, International Journal of Innovative Technology and Exploring Engineering, Vol. 8 no. 11, pp: 3860-3864, (2019).

23. Joshi S. V \& Kadu M. S., Role of alkaline activator in development of eco-friendly fly ash based geo polymer concrete, International Journal of Environmental Science and Development, 3(5), 417 (2012).

24. Palomo A \& Fernández-Jiménez A., Alkaline activation, procedure for transforming fly ash into new materials. Part I: Applications, World of Coal Ash (WOCA) Conference (pp. 1-14) (May, 2011). 
25. Jindal B. B., Investigations on the properties of geopolymer mortar and concrete with mineral admixtures: A review, Construction and Building Materials, 227, 116644 (2019).

26. Khan M. S, Shariq M, Akhtar S \& Masood A., Performance of high-volume fly ash concrete after exposure to elevated temperature, Journal of the Australian Ceramic Society, 1-14 (2019).

27. Jia Z, Chen C, Shi J, Zhang Y, Sun Z \& Zhang P., The microstructural change of $\mathrm{CSH}$ at elevated temperature in Portland cement/GGBFS blended system. Cement and Concrete Research, 123, 105773 (2019).

28. Pan Z, Sanjayan J. G \& Kong D. L., Effect of aggregate size on spalling of geopolymer and Portland cement concretes subjected to elevated temperatures. Construction and Building Materials, 36, 365-372 (2012).

29. Nadeem A, Memon S. A \& Lo T. Y., The performance of fly ash and metakaolin concrete at elevated temperatures, Construction and Building Materials, 62, 67-76 (2014).

30. Tummala Suresh Kumar, Kosaraju Satyanarayana, Materials Today: Proceeding, 26 (2), 3228-3233, (2020)

31. Thomas C, Rico J, Tamayo P, Ballester F, Setién J \& Polanco J. A., Effect of elevated temperature on the mechanical properties and microstructure of heavyweight magnetite concrete with steel fibres, Cement and Concrete Composites, 103, 80-88 (2019).

32. Ahmad S, Umar A, Masood A \& Nayeem M., Performance of self-compacting concrete at room and after elevated temperature incorporating Silica fume, Advances in concrete construction, 7(1), 31 (2019).

33. Lee W. Y, Husin S. S, Thangaveloo T \& Hejazi F., Forensic engineering of fire damaged concrete structures-a review-. In IOP Conference Series: Earth and Environmental Science (Vol. 357, No. 1, p. 012021). IOP Publishing (November, 2019).

34. Khalaf $\mathrm{J} \&$ Huang Z., The bond behaviour of reinforced concrete members at elevated temperatures, Fire Safety Journal, 103, 19-33 (2019).

35. Sharma A, Bošnjak J \& Bessert S., Experimental investigations on residual bond performance in concrete subjected to elevated temperature, Engineering Structures, 187, 384-395 (2019).

36. Junaid M. T, Kayali O \& Khennane A., Response of alkali activated low calcium fly-ash based geopolymer concrete under compressive load at elevated temperatures, Materials and Structures, 50(1), 50 (2017).
37. Hussin M. W, Bhutta M. A. R, Azreen M, Ramadhansyah P. J \& Mirza J., Performance of blended ash geopolymer concrete at elevated temperatures, Materials and Structures, 48(3), 709720 (2015).

38. Mallikarjuna Rao $G$ \& Gunneswara Rao T. D, A quantitative method of approach in designing the mix proportions of fly ash and GGBS-based geopolymer concrete, Australian Journal of Civil Engineering, 16(1), 53-63 (2018).

39. Rajagiri A, MN Sandhya, Nawaz S, Suresh Kumar T, E3S Web of Conferences 8701004 (2019).

40. Hardjito D, Wallah, S. E, Sumajouw D. M. J, \& Rangan B. V., Introducing fly ash-based geopolymer concrete: manufacture and engineering properties, 30th conference on our world in concrete \& structures (Vol. 24) (August, 2005).

41. Kong D L \& Sanjayan J G., Effect of elevated temperatures on geopolymer paste, mortar and concrete, Cement and concrete research, 40(2), 334339 (2010).

42. Mane S \& Jadhav H. S., Investigation of geopolymer mortar and concrete under high temperature. Magnesium, 1(5) (2012).

43. Shaikh F. U. A \& Vimonsatit V., Compressive strength of fly-ash-based geopolymer concrete at elevated temperatures, Fire and materials, 39(2), 174-188 (2015).

44. Aslani F., Thermal performance modeling of geopolymer concrete, Journal of Materials in Civil Engineering, 28(1), 04015062 (2016).

45. Li L, Shi L, Wang Q, Liu Y, Dong J, Zhang H \& Zhang, G., A review on the recovery of fire-damaged concrete with post-fire-curing. Construction and Building Materials, 237, 117564 (2020).

46. Poon C. S, Azhar S, Anson M \& Wong Y. L., Strength and durability recovery of fire-damaged concrete after post-fire-curing, Cement and concrete research, 31(9), 1307-1318(2001).

47. Junru R, Huiguo C, Ruixi D \& Tao S., Behavior of combined fly ash/GBFS-based geopolymer concrete after exposed to elevated temperature, IOP Conference Series: Earth and Environmental Science (Vol. 267, No. 3, p. 032056). IOP Publishing (May, 2019).

48. Lee W. Y, Husin S. S, Thangaveloo T \& Hejazi F., Forensic engineering of fire damaged concrete structures: a review, In IOP Conference Series: Earth and Environmental Science (Vol. 357, No. 1, p. 012021). IOP Publishing (November, 2019). 